\title{
Comparison of Wood Density and Water Content Between Dry Evergreen and Dry Deciduous Forest Trees in Central Cambodia
}

\author{
Tanaka KENZO'*, Makoto SANO ${ }^{1}$, Reiji YONEDA ${ }^{2,3}$ and Sophal CHANN ${ }^{4}$ \\ ${ }^{1}$ Forestry and Forest Products Research Institute (Tsukuba, Ibaraki 305-8687, Japan) \\ 2 Japan International Research Center for Agricultural Sciences (Tsukuba, Ibaraki 305-8686, Japan) \\ ${ }^{4}$ Forest-Wildlife Research and Development Institute, Forestry Administration (Phnom Penh, \\ Cambodia)
}

\begin{abstract}
We compared wood density (WD) and water content (WC) between a dry evergreen forest (DEF) and dry deciduous forest (DDF) in central Cambodia. Wood core samples of 53 species from DEF and 54 species from DDF were collected. Average WD and WC in all species were similar between DEF $\left(0.64 \mathrm{~g} / \mathrm{cm}^{3}\right.$ of WD; $0.40 \mathrm{~g} / \mathrm{cm}^{3}$ of WC) and DDF $\left(0.64 \mathrm{~g} / \mathrm{cm}^{3}\right.$ of WD; $0.42 \mathrm{~g} / \mathrm{cm}^{3}$ of WC), although the average WC of five tree species that appeared in both forest types was higher in DDF than that in DEF. Tree size effects on WD and WC were negligible in both DEF and DDF. Intraspecific differences of those effects on WD and WC were also not observed in major canopy species in DDF and DEF, except for WD of Shorea obtusa in DDF, whose value increased with increasing tree diameter. Tree life-forms such as canopy, subcanopy, and understory species did not affect WD and WC in both forest types, although canopy gap species in DEF showed the smallest WD among the life-forms. The relationships between WD and WC in DEF and DDF were negatively correlated, and both regression equations did not differ between forest types. Overall, there were little differences on average WD and WC between DEF and DDF trees, even though their species composition and tree ecological traits were significantly different between forest types in central Cambodia.
\end{abstract}

Discipline: Forestry and forest products

Additional key words: Biomass, plant functional group, REDD+, wood specific gravity, Dipterocarpaceae

\section{Introduction}

Tropical dry forests occur in the Indochina Peninsula, which experiences severe dry spells, sometimes lasting several months without rainfall. In this region, there are two distinct types of dry forests in lowland areas (Ashton 2014, Hozumi et al. 1969, Ogawa et al. 1965), namely dry evergreen forests (DEF) and dry deciduous forests (DDF). Cambodia is located in the center of the peninsula and still maintains relatively high forest coverage (59.1\% in 2006) compared with adjacent countries in the same monsoon area of the peninsula, such as Thailand and Vietnam, although the loss of forest area has accelerated in recent decades (FAO 2007). DEF and DDF are major forest types and account more than $70 \%$ of the total forest area in Cambodia (Srun 2014). Each forest type consists of significantly different tree species with different ecological traits, such as leaf phenology, maximum tree height, and photosynthesis (Hozumi et al. 1969, Iida et al. 2013, 2016, Ishida et al. 2006, 2010, Ogawa et al. 1965). Soil conditions also differ between the forest types; DEF usually has a thick soil depth, whereas DDF shows a

This paper reports the results obtained in the project on "Estimation and simulation of carbon stock change of tropical forest in Asia (2011-2014)" funded by Japan's Ministry of Agriculture, Forestry and Fisheries, and was partly supported by the Global Environment Research Account for National Institutes, Ministry of the Environment, Japan.

Present address:

${ }^{3}$ Shikoku Research Center, Forestry and Forest Products Research Institute (Kochi, Kochi 780-8077, Japan)

*Corresponding author: e-mail mona@affrc.go.jp

Received 14 June 2016; accepted 10 January 2017. 
thinner soil depth and drier soil conditions (Sakurai et al. 1998, Toriyama et al. 2011). Several researchers have been pointed out that a thicker soil depth with large water storage in DEF may allow leaf transpiration activity during the dry season, and consequently trees could maintain evergreen leaves (Murata et al. 2012, Ohnuki et al. 2008). Thus, drought stress for forest trees may be higher in DDF, which has smaller soil water storage as compared with DEF.

The traits of stem woody parts, namely wood density and water content, have a strong relationship with their functional traits, such as drought tolerance, crown architecture, growth rate, survival, and photosynthesis, especially in tropical forests (Bucci et al. 2004, Hiromi et al. 2012, Inoue et al. 2015, Ishida et al 2008, Kenzo et al. 2011, Markesteijn et al. 2011, Martin et al. 2013, Santiago et al. 2004). For example, trees with low wood density exhibit a faster growth rate compared with trees of high wood density, whereas trees with high wood density usually have a high survival rate due to their stronger resistance to physical stress, pathogens, and pest attacks (Curran et al. 2008, King et al. 2005, 2006, Kitajima 1994). Stem water storage is also related to wood density and may partially compensate for increases in drought stress in Central and South American dry tropical forest trees (Holbrook et al. 1995, Meinzer et al. 2004). Thus, a recent synthesis has been proposed as an integration of a wood economics spectrum and as a pivotal axis of plant functional strategies (Chave et al. 2009).

Wood density also has another important factor in identifying forest biomass (Baker et al. 2004), because the coefficients of allometric equations depend on wood density (Chave et al. 2005, 2014, Komiyama et al. 2005). Kenzo et al (2009ab) reported that allometric equations obtained from trees with high wood density provided a much higher estimate of the biomass of low wood density trees having the same tree diameter, which was overestimated by more than twice in Malaysian tropical forests. In addition, several studies reported that variations in community-averaged wood density among different forest types significantly affected forest biomass in South American tropical forests (Malhi et al. 2006, Saatchi et al. 2007, but see Stegen et al. 2009).

Environmental conditions, such as precipitation and soil fertility, may affect wood density and water content (Fortunel et al. 2012, 2014, Onoda et al. 2010, Sungpalee et al. 2009). In fact, tree species in drier areas had higher wood density than those in rich rainfall areas in Central and South American tropical forests (BarajasMorales 1987, Chave et al. 2006, Holbrook et al. 1995, Lohbeck et al. 2013, Wiemann \& Williamson 2002). A slower growth rate in drier forest trees than that of wetter forest trees may cause this difference (Barajas-Morales 1987). Several tree species with low growth rates such as understory trees also showed higher wood density than fast growing species such as pioneer species (MullerLandau 2004, Poorter 2008, Suzuki 1999). High wood density may be adaptive to a dry environment because those trees have high tolerance to drought stress with low stem water potential, by having high physical strength with thick cell walls (Holbrook et al. 1995, Markesteijn et al. 2011, Onoda et al. 2010). Lower soil fertility also affects tree wood density. Slik et al. (2010) reported that tropical heathy forest trees under depleted soil conditions showed relatively high wood density compared with lowland dipterocarp forest trees in Borneo. However, variations in wood density among the forest types in Southeast Asia are not clear compared with those among South American tropical forests (Barajas-Morales 1987, Chave et al. 2006, Turner 2001). In addition, tree life-forms such as canopy, understory, and canopy gap species may affect these woody traits, because several plant functional traits, including wood and leaf traits, significantly differ between the life-forms in several forest biomes (Ichie et al. 2016, Iida et al. 2012, Kenzo et al. 2007, 2016a, Tanaka-Oda et al. 2016, Thomas 1996).

In the present study, we hypothesized that trees in DDF might have high wood density and water content compared with those in DEF, because the growth rate of DDF trees might be limited by a drier soil condition and stem water storage might have a substantial role against the mitigation of drought stress in DDF. The tree wood stem consists of solid wood material, and gas and water fractions (Colgan et al. 2014, Poorter 2008). Despite the high wood density (high solid wood material), increased water content in DDF trees in our expectation may be achieved by the gas fraction, which can be filled by water (Colgan et al. 2014). In fact, a substantial amount in the stem volume occupied by the gas fraction has been reported in temperate $30 \%$ on average and maximum of $60 \%$, Gartner et al. 2004) and tropical forest trees ( $15 \%$ on average and maximum of $38 \%$, Poorter 2008), respectively. To test our hypothesis, we compared the wood density and water content of various species that included the dominant canopy species in the DDF and DEF studied in central Cambodia. We also focused on the differences in wood traits between the tree life-forms in both forest types.

\section{Materials and methods}

\section{Study site}

This study was conducted in four forest stands: two DEF stands, one DDF stand in Kampong Thom Province 
$\left(12^{\circ} 44^{\prime} \mathrm{N}, 105^{\circ} 28^{\prime} \mathrm{E}\right)$, and one DDF stand in Kratie Province $\left(12^{\circ} 55^{\prime} \mathrm{N}, 106^{\circ} 11^{\prime} \mathrm{E}\right)$, Cambodia. We chose these sites as representative forests for DDF and DEF in central Cambodia. Both annual rainfall (approx. 1500-1700 mm) and mean temperature (approx. $27^{\circ} \mathrm{C}$ ) are similar between the provinces (Iida et al. 2013, 2016). Most rainfall occurs during the rainy season from May to October (Iida et al. 2013, 2016). The vegetation at the DEF sites primarily consisted of species from Clusiaceae, Dipterocarpaceae, Leguminosae, and Myristicaceae families (Kenzo et al. 2012). Most of the canopy trees in DEF were 30-40 m in height (Fig. 1). The soil type in DEF was primarily Acrisols based on FAO and WRB classification, and the depth of the soil layer reached $10 \mathrm{~m}$ (Ohnuki et al. 2008).

The vegetation at the DDF sites primarily consisted of species from Combretaceae, Dipterocarpaceae, and Leguminosae families (Kenzo et al. 2016c). All tree species shed leaves during the dry season, although leaf phenology in canopy trees significantly varied according to species (Iida et al. 2016). Most canopy trees were 12-20

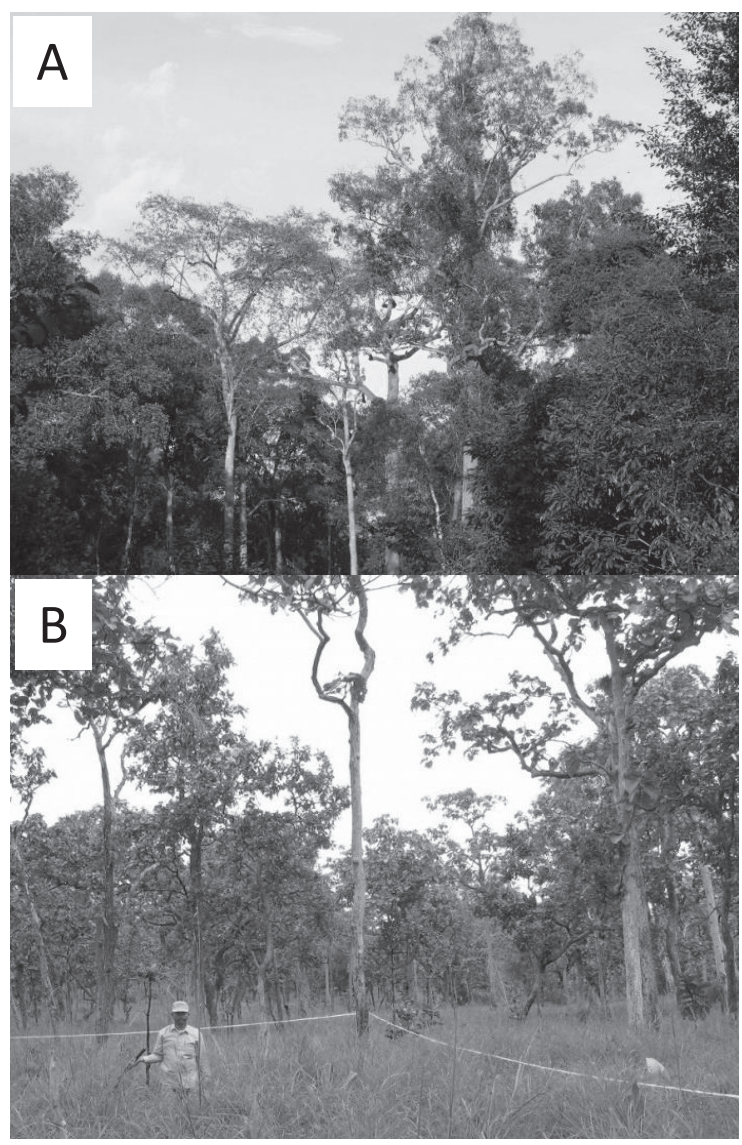

Fig. 1. Aspects of studied forest stands.

A: dry evergreen forest (DEF) with 30-40 m canopy height in Kampong Thom Province, B: dry deciduous forest (DDF) with 15-20 m canopy height in Kratie Province. $\mathrm{m}$ in height. Tall grass (approx. $1 \mathrm{~m}$ in height) and dwarf bamboo (Vietnamosasa pusilla, Poaceae) densely covered the forest floor (Fig. 1, Kenzo et al. 2016c). The surface geology consisted of old sedimentary rocks and terrace gravel, and the soil type was Plinthosol according to the FAO classification: the depth of the soil layer ranged from 100 to $300 \mathrm{~cm}$ (Ohnuki et al. 2008). Another DDF stand in Kampong Thom Province was also similar in terms of vegetation and environmental conditions.

\section{Wood core sampling and plant materials}

We collected wood core samples (approx. 5-20 cm in length; one or two samples per tree) at approximately $1 \mathrm{~m}$ in height by using an increment bore, mainly during the early dry season from November to December. In total, 71 tree individuals representing 53 species of 27 families from DEF and 116 tree individuals representing 54 species of 22 families from DDF were collected (Appendixes 1 \& 2). Most collected species were common tree species, which covered dominant canopy species, in DEF and DDF in Kampong Thom and Kratie Provinces (Tagane et al. 2015, Top et al. 2009, Toyama et al. 2013). The nomenclature was checked in The Plant List, version 1.1 (http://www.theplantlist.org/). Only five species (Memecylon scutellatum, Parinari anamensis, Symplocos cochinchinensis, Syzygium antisepticum, and Syzyium oblatum) were collected in both forest types (Appendixes 1 \& 2). Fresh weight and volume of the sampled cores were immediately measured to calculate the water content. These cores were oven-dried at $100^{\circ} \mathrm{C}$ for $>72 \mathrm{~h}$ until reaching a constant mass. Wood density was determined as wood dry mass per fresh volume and wood water content as wood water mass per fresh volume (Suzuki 1999).

\section{Categories of tree life-forms}

Tree species fell into four life-form categories in DEF and three categories in DDF based on mature tree height (understory, subcanopy, and canopy species) and whether canopy gap species in DEF. The height of mature trees and life-form categories of each species were determined by observation and literature surveys. We primarily followed the Field Guide to Forest Trees of Northern Thailand (Gardner et al. 2000), the incomplete series of the Flora of Thailand, and other flora records in Cambodia (Pauline 2000, Tagane et al. 2015, Toyama et al. 2012, 2013). Thereafter, the tree species were classified into three categories based on mature height and field observation: forest understory $(\leq 15 \mathrm{~m})$, subcanopy (16$24 \mathrm{~m}$ ), and canopy ( $\geq 25 \mathrm{~m}$ ) species for DEF; and forest understory $(\leq 8 \mathrm{~m})$, subcanopy $(9-14 \mathrm{~m})$, and canopy ( $\geq$ $15 \mathrm{~m})$ species for DDF. Tree species that primarily grow 
in canopy gaps were classified independently (canopy gap species) in DEF, although we did not categorize gap species for trees in DDF due to an unclosed forest canopy in the forest type (Fig. 1).

\section{Statistical analysis}

We conducted analysis of variance (ANOVA) with Tukey's HSD multiple comparison tests to determine the differences in wood traits between both forest types and life-forms. We also conducted paired $t$-tests to determine the differences in wood traits of five tree species
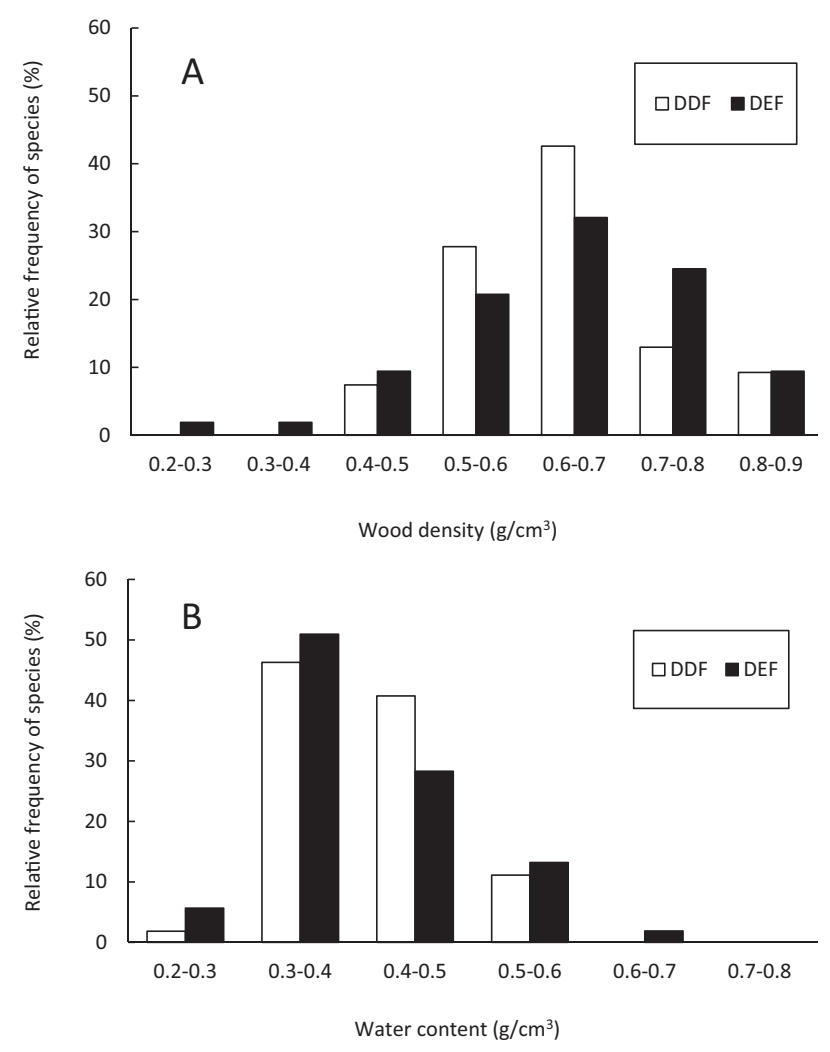

Fig. 2. Relative frequency of species in wood density (A) and water content (B) in dry deciduous forest (DDF) and dry evergreen forest (DEF) in Cambodia. that appeared in both forest types. Differences in the regression equations of both forest types between wood density and water content were determined by analysis of covariance (ANCOVA). All statistical tests were conducted with SPSS for Windows, version 17.0 (SPSS Inc., Chicago).

\section{Results and discussion}

\section{Average wood density and water content in DEF and DDF}

Average wood density and water content in all species were similar between DEF and DDF, although several tree species in DEF showed lower wood density than DDF trees (Fig. 2, Table 1). The similarities in wood traits between forest types were not consistent with our prediction that the density and water content of DDF trees have higher values than those of DEF trees. Although a precise reason for the minor differences between the forest types in central Cambodia was unknown, trees in DEF may also suffer strong drought stress, which may adversely affect wood density and water content, especially during the dry season. In fact, leaf-level physiological traits in various DEF tree species during the dry season revealed evidence of strong drought stress, such as stomatal closing in taller trees (e.g., taller than $10 \mathrm{~m}$ ), even though they maintained leaf photosynthetic ability by absorbing groundwater (Kenzo et al. 2012). Moreover, large interannual variations of rainfall in Cambodia may cause strong drought stress for DEF trees because exceptional leaf shedding occurs in evergreen canopy trees during the dry season in years of extremely low rainfall (Iida et al. 2013). Trees in DEF with high wood density may afford high tolerance to drought stress with low stem water potential by having high physical strength with thick cell walls during the dry season (Holbrook et al. 1995, Onoda et al. 2010), especially in tall canopy trees with large gravity potential (Kenzo et al. 2015, Ryan et al. 2006). Several researchers also found that tree species

Table 1. Average, minimum (Min.) and maximum (Max.) values of wood density and wood water content in all dry evergreen (DEF) and dry deciduous forest (DDF) trees.

\begin{tabular}{|c|c|c|c|c|c|c|}
\hline \multirow[t]{2}{*}{ Forest type } & \multicolumn{3}{|c|}{ Wood density $\left(\mathrm{g} / \mathrm{cm}^{3}\right)$} & \multicolumn{3}{|c|}{ Wood water content $\left(\mathrm{g} / \mathrm{cm}^{3}\right)$} \\
\hline & Average & Min. & Max. & Average & Min. & Max. \\
\hline DEF & $0.643 \pm 0.02$ & 0.290 & 0.863 & $0.400 \pm 0.01$ & 0.269 & 0.666 \\
\hline \multirow[t]{2}{*}{ DDF } & $0.642 \pm 0.01$ & 0.421 & 0.880 & $0.419 \pm 0.01$ & 0.283 & 0.571 \\
\hline & $\mathrm{ns}, P=0.99$ & - & - & $\mathrm{ns}, P=0.19$ & - & - \\
\hline
\end{tabular}

Values are mean \pm SE. $P$ values for ANOVA test between DEF and DDF trees. Statistical differences in average wood density and water content were not observed between the forest types (ns, ANOVA, $P>0.05$ ). 
with high wood density were able to survive the severe drought event during 1997-1998 El Niño as compared with lower wood density species in Bornean tropical rainforest (Bebber 2000, Hiromi et al. 2012). Further large datasets on community-level wood density and water content from broad climate zones in tropical Southeast Asia are needed to clarify the precise relationship between wood traits and environmental conditions, especially for precipitation and dry spell length. In fact, lower community-level wood density has been reported in tropical rainforests in Kalimantan $\left(0.56 \mathrm{~g} / \mathrm{cm}^{3}\right.$, Suzuki 1999) and Brunei $\left(0.59 \mathrm{~g} / \mathrm{cm}^{3}\right.$, Osunkoya et al. 2007), with a large amount of precipitation (approximately $2700-4000 \mathrm{~mm}$ per year) and few dry spells compared with Cambodian forests. In addition, the average wood density in South American tropical rainforests usually increased with decreasing precipitation and a longer dry spell (Barajas-Morales 1987, Chave et al. 2006, Lohbeck et al. 2013, Wiemann \& Williamson 2002), although several researchers also could not find a clear relationship between wood density and rainfall in these regions (Ter Steege \& Hammond 2001, Williamson 1984).

\section{Wood density and water content in five tree species appearing in both forest types}

We obtained conflicting results for wood water content at intraspecific and community levels in DEF and DDF, although the wood density between forest types was similar at both levels. Five tree species (Memecylon scutellatum, Parinari anamensis, Symplocos cochinchinensis, Syzygium antisepticum, and Syzygium oblatum) that appeared in both forest types showed a higher wood water content in DDF compared with DEF (Appendixes $1 \& 2$, Table 2), whereas average water content in all species was similar between the forest types (Table 1). This difference may indicate that responses on wood water content to environmental conditions in both forest types differ at intraspecific and community levels. The ecophysiological functions of stem water storage may explain intraspecific differences in water content between the forest types. Larger stem water storage in the DDF condition contributes to flushing new leaves and refilling vessels in sap wood before the first rain in the dry season, because the wood water content in the stems in several DDFs in Central and South America significantly decreased in the dry season compared with that in the wet season (Borchert 1994, Holbrook et al. 1995, Sobrado 1993). In addition, larger water storage in the stem could mitigate severe drought stress at both diurnal and annual scales in tropical dry forest trees (Holbrook et al. 1995, Meinzer et al. 2004). A more detailed ecophysiological approach could provide a clear understanding of the roles of stem water content at intraspecific and community levels in dry tropical forests in Cambodia.

\section{Wood traits in relation to tree size and life-forms}

Wood density and water content were similar between both tree sizes and size-related life-forms (e.g., canopy, subcanopy, understory) in DEF and DDF (Fig. 3, Table 3), despite the negative relationship between tree size and wood density reported in several tropical rainforest trees (Becker 2012, Poorter et al. 2010, Thomas 1996). Intraspecific variables between tree size (both tree diameter and height) were also small in five canopy species (Terminalia tomentosa, Dipterocarpus tuberculatus, Shorea obtusa, S. siamensis, and Xylia xylocarpa), which frequently appeared in the plot in DDF, except for a positive relationship between tree diameter and wood density in S. obtusa (Fig. 4). The size-related changes in wood density and water content were also not significant in three canopy tree species (Anisoptera costata, Dipterocarpus costatus, and Sindora siamensis), which frequently appeared in the DEF studied (Fig. 5). In contrast, we found a significantly lower wood density of canopy gap species in DEF (Table 3). This lower wood density of canopy gap species is consistent with many previous studies that reported significantly lower wood density in canopy gap and secondary forest trees, due to their faster growth rate than late successional species in tropical forests in Southeast Asia (Kenzo et al. 2009ab, Osunkoya et al. 2007, Suzuki 1999). Conversely, the similarity of wood density between height-related life-forms in Cambodian dry forests (Table 3) may be related to severe drought stress during longer dry spells than in moist tropical rainforests. In tropical rainforests, size-related differences in wood traits, especially in wood density, were explained in the context of light requirements (Poorter et al. 2010). For example, low

Table 2. Average wood density and water content in five species (Memecylon scutellatum, Parinari anamensis, Symplocos cochinchinensis, Syzygium antisepticum, and Syzygium oblatum) that appeared in both dry evergreen (DEF) and dry deciduous forest (DDF).

\begin{tabular}{lcc}
\hline \hline Forest type & Wood density $\left(\mathrm{g} / \mathrm{cm}^{3}\right)$ & Water content $\left(\mathrm{g} / \mathrm{cm}^{3}\right)$ \\
\hline DEF & $0.736 \pm 0.05$ & $0.386 \pm 0.03$ \\
DDF & $0.632 \pm 0.02$ & $0.438 \pm 0.03$ \\
& $\mathrm{~ns}, P=0.07$ & $*, P=0.04$ \\
\hline
\end{tabular}

Values are mean \pm SE. $P$ values for paired $t$-test between DEF and DDF trees. The asterisk (*) indicates significant differences between forest types by paired $t$-test $(P<0.05)$, ns indicates nonsignificant. 
wood density species show an efficient height expansion to attain better light conditions in the exposed canopy, whereas high wood density species with a low growth rate show an efficient horizontal crown expansion to enhance current light interception and persistence in the shaded forest understory (Iida et al. 2012). In contrast to tropical rainforests, light is a lesser limiting resource than water in dry tropical forests, especially in DDF. Consequently, the relationship between wood traits and height-related life-forms, which primarily reflect
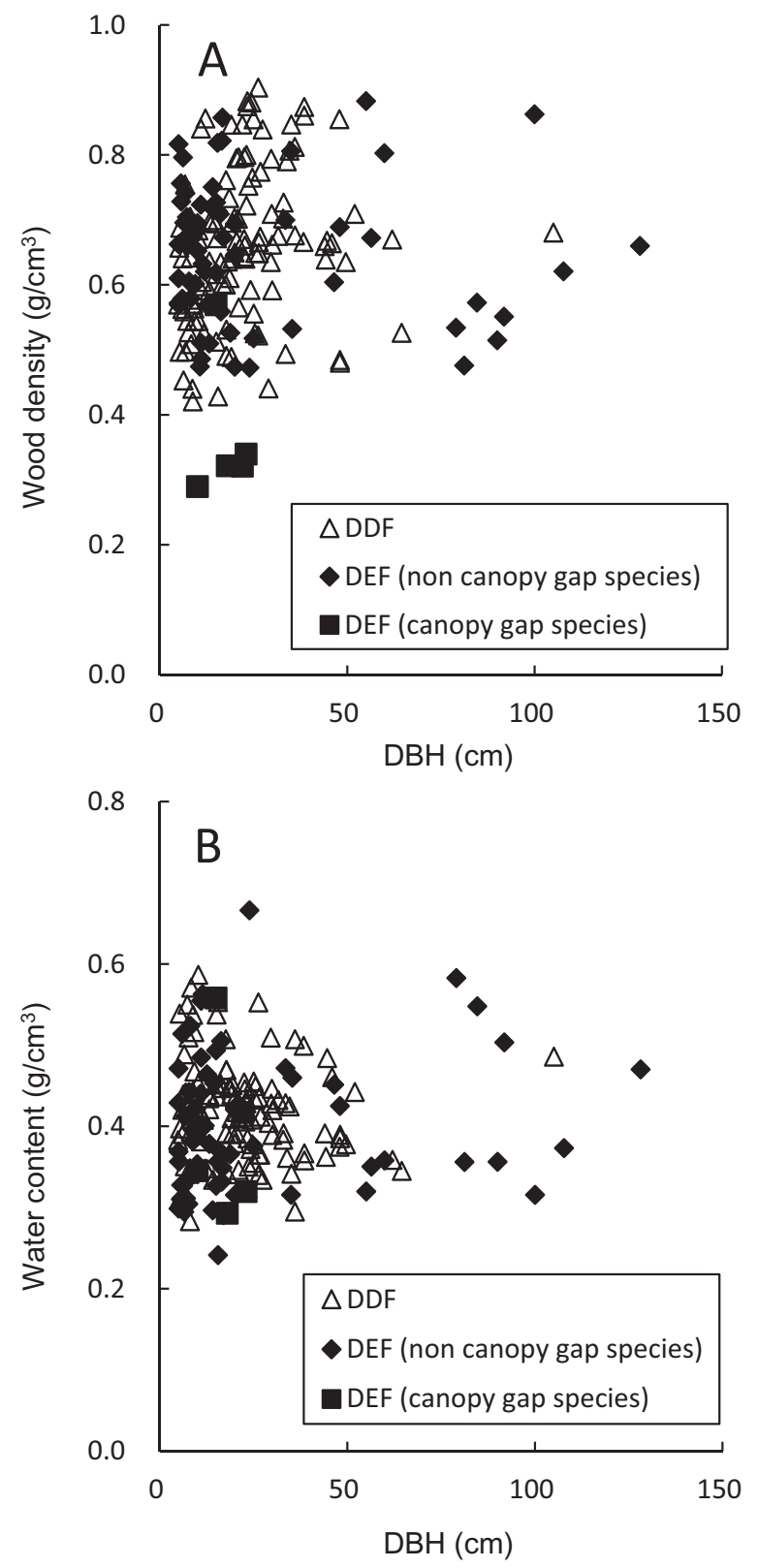

Fig. 3. Diameter at breast height $(\mathrm{DBH})$ in relation to wood density (A) and water content $(B)$ in all individuals in dry deciduous forest (DDF) and dry evergreen forest (DEF) in Cambodia. light environment, may become weaker than that in moist tropical rainforests. Poorter and Kitajima (2007) also reported that the relationship between wood traits, especially stored resources, and light requirements is strong in moist tropical rainforests where species sort out along a light gradient; however, the relationship disappears in tropical dry forests where light is a less limiting resource and species sort out along drought or fire gradients. In a tropical dry forest, an increasing path length for water to travel to reach transpiring leaves from dry soil and an increasing gravitational potential can increase drought stress in taller canopy species (Meinzer et al. 2004, Ryan et al. 2006). In fact, leaves in DEF suffer strong drought stress when attached at $>10 \mathrm{~m}$ in height, which is applicable to canopy and subcanopy lifeforms in the present study during the dry season (Kenzo et al. 2012). Therefore, higher wood density in taller trees, especially in DEF where canopy trees reached 40 $\mathrm{m}$ height, may help to overcome the vertical increment of drought stress through low xylem water potential. These environmental differences between moist rainforests and dry forests may induce different responses on wood traits between life-forms. In addition, the small range of tree height in DDF may also result in similar wood traits between both life-forms and tree sizes. Similar small intraspecific differences in wood density were also reported in a tropical mountain forest in Thailand, even after including individuals of various sizes in the analysis (Sungpalee et al. 2009). Small variations in wood density from pith to bark in several Cambodian trees, especially Dipterocarpaceae (Nakano \& Kaburagi 1966), were similar to the small differences observed in wood density between tree sizes in this study.

\section{Relationship between wood density and water content}

Negative relationships between wood density and water content were observed in DEF and DDF (Fig. 6), and both regression equations were similar between the forest types $(P>0.05$, ANCOVA). This trend indicated that trees with lower wood density tended to contain a large amount of stored water in their stems. Trees with low wood density usually consisted of many parenchyma cells and lumen fractions; as a result, these components could contain a large amount of water (Barajas-Morales 1985, Holbrook et al. 1995). In contrast, several researchers found that the relationship in tropical rainforest trees was less significant and even trees with low wood density showed low water content (Kenzo et al. 2016b, Suzuki 1999, Osunkoya et al. 2007). Thus, the relationship between wood density and water content may differ among forest types in Southeast Asia. 
Table 3. Number of species (No.), average diameter at breast height (DBH, cm), wood density (g/cm $\left.{ }^{3}\right)$, and water content $\left(\mathrm{g} / \mathrm{cm}^{3}\right)$ between life-forms in dry evergreen (DEF) and dry deciduous forest (DDF).

\begin{tabular}{|c|c|c|c|c|c|c|c|c|}
\hline \multirow[b]{2}{*}{ Life form } & \multicolumn{4}{|c|}{ Dry evergreen forest (DEF) } & \multicolumn{4}{|c|}{ Dry deciduous forest (DDF) } \\
\hline & No. & DBH & Wood density & Water content & No. & DBH & Wood density & Water content \\
\hline Understory & 21 & $9 \pm 1^{b}$ & $0.673 \pm 0.02$ a & $0.389 \pm 0.02$ & 14 & $12 \pm 2^{b}$ & $0.620 \pm 0.02$ & $0.404 \pm 0.02$ \\
\hline Subcanopy & 17 & $17 \pm 2^{b}$ & $0.648 \pm 0.02^{\mathrm{a}}$ & $0.395 \pm 0.02$ & 12 & $16 \pm 3^{b}$ & $0.610 \pm 0.03$ & $0.453 \pm 0.02$ \\
\hline Canopy & 12 & $41 \pm 10^{\text {a }}$ & $0.640 \pm 0.04{ }^{a}$ & $0.423 \pm 0.03$ & 28 & $29 \pm 4^{\text {a }}$ & $0.666 \pm 0.02$ & $0.410 \pm 0.01$ \\
\hline \multirow[t]{2}{*}{ Canopy gap } & 3 & $15 \pm 3^{a b}$ & $0.397 \pm 0.09^{b}$ & $0.417 \pm 0.07$ & N/A & N/A & N/A & N/A \\
\hline & - & $P=0.00$ & $P=0.01$ & ns, $P=0.27$ & - & $P=0.01$ & $\mathrm{~ns}, P=0.22$ & $\mathrm{~ns}, P=0.11$ \\
\hline
\end{tabular}

Values are mean \pm SE. $P$ values for ANOVA test between life-forms. Different superscripted lowercase letters attached to these values indicate significantly different pairwise differences, and ns indicates nonsignificant (ANOVA, Tukey's HSD multiple comparisons tests; $P<0.05)$. N/A indicates not applicable.
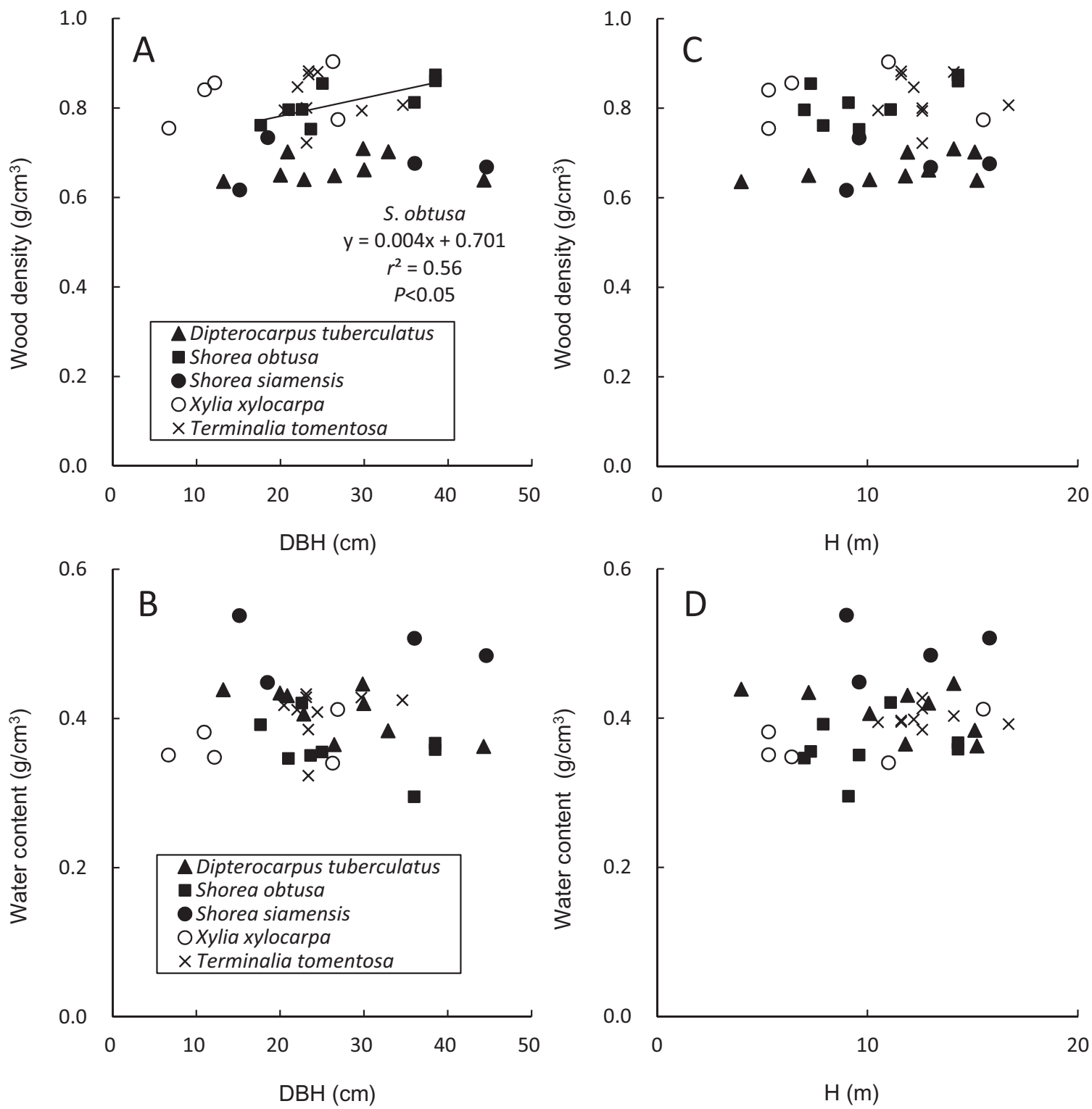

Fig. 4. Diameter at breast height $(\mathrm{DBH})$ and tree height $(\mathrm{H})$ in relation to wood density $(\mathrm{A}, \mathrm{C})$ and water content (B, D) in major species in dry deciduous forest (DDF) in Cambodia. 


\section{Conclusions}

We found that average wood density and water content in all species were similar between DEF and DDF in central Cambodia, whereas five tree species that appeared in both forest types showed significantly higher water content in DDF than in DEF. Higher wood water content in these species in DDF may contribute to high drought tolerance in drier soil conditions compared with DEF. In addition, the wood traits were also similar between tree sizes and/or size-related life-forms (e.g., canopy, subcanopy, understory) in both forest types, except for canopy gap species, which showed lower wood density compared with other life-forms in DEF. These similarities in wood density between the forest types, life-forms, and tree sizes also contribute to the accurate estimation of forest biomass by using community-averaged wood
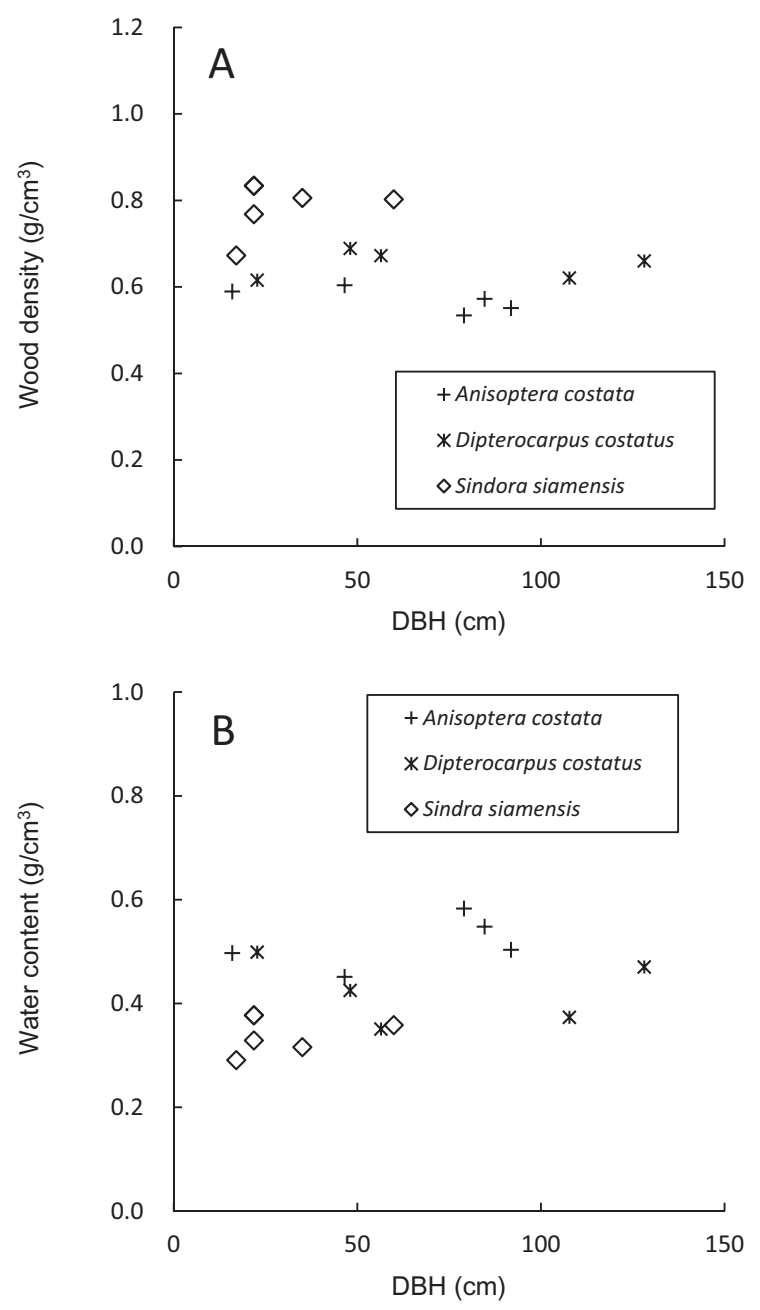

Fig. 5. Diameter at breast height (DBH) in relation to wood density (A) and water content (B) in three canopy species in dry evergreen forest (DEF) in Cambodia. density and remote-sensed data, such as stand volume and height in central Cambodia (Baker et al. 2004, Chave et al. 2006, Malhi et al. 2006).

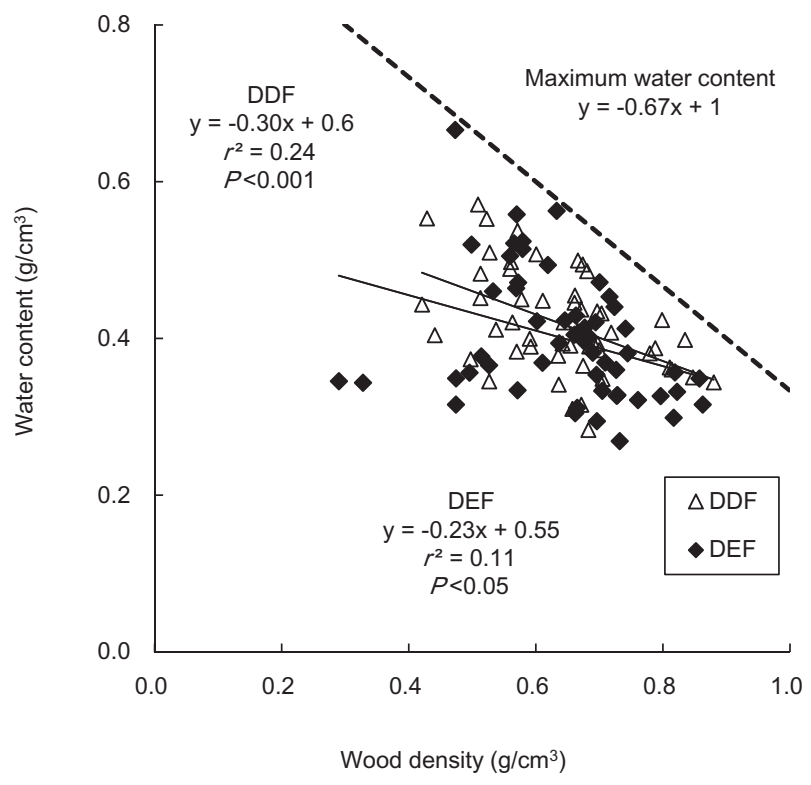

Fig. 6. Relationship between wood density and water content in dry deciduous forest (DDF) and dry evergreen forest (DEF) in Cambodia. The regression equations did not significantly differ between the forest types (ANCOVA, $P \boldsymbol{>} \mathbf{0 . 0 5}$ ).

Dotted line indicates theoretical equation of maximum water content (Suzuki 1999).

\section{Acknowledgements}

This study was conducted under the project "Estimation and simulation of carbon stock change of tropical forest in Asia (2011-2014)" funded by Japan's Ministry of Agriculture, Forestry and Fisheries, and was partly supported by the Global Environment Research Account for National Institutes, Ministry of the Environment, Japan. The authors also wish to thank to the Forestry Administration, the Forest and Wildlife Science Research Institute of Cambodia, and Drs. A. Shimizu, K. Tamai, T Shimizu, S. Iida, N. Kabeya, T. Sato, Y. Ohnuki, and E. Itoh for their kind support of this study.

\section{References}

Ashton, P. S. (2014) On the Forests of Tropical Asia: Lest the memory fade. Kew Publishing, Kew, UK, pp.670.

Baker, T. R. et al. (2004) Variation in wood density determines spatial patterns in Amazonian forest biomass. Glob. 
Change Biol., 10, 545-562.

Barajas-Morales, J. (1985) Wood structural differences between trees of two tropical forests in Mexico. IAWA J., 6, 355-364.

Barajas-Morales, J. (1987) Wood specific gravity in species from two tropical forests in Mexico. IAWA J., 8,143-148.

Bebber. D. P. (2000) Dipterocarp timber properties and drought tolerance. Malay. For., 63, 179-185.

Becker, G. S. et al. (2012) Relations between wood variables and how they relate to tree size variables of tropical African tree species. Trees, 26, 1101-1112.

Borchert, R. (1994) Soil and Stem Water Storage Determine Phenology and Distribution of Tropical Dry Forest Trees. Ecology, 75, 1437-1449.

Bucci, S. J. et al. (2004) Functional convergence in hydraulic architecture and water relations of tropical savanna trees: from leaf to whole plant. Tree Physiol., 24, 891-899.

Chave. J. et al. (2005) Tree allometry and improved estimation of carbon stocks and balance in tropical forests. Oecologia, $145,87-99$

Chave. J. et al. (2006) Regional and phylogenetic variation of wood density across 2456 neotropical tree species. Ecol. Appl., 16, 2356-2367.

Chave. J. et al. (2009) Towards a worldwide wood economics spectrum. Ecol. Let., 12, 351-366.

Chave. J. et al. (2014) Improved allometric models to estimate the aboveground biomass of tropical trees. Glob. Change Biol., 20, 3177-3190.

Colgan, M. S. et al. (2014) Structural relationships between form factor, wood density, and biomass in African savanna woodlands. Trees, 28, 91-102.

Curran, T. J. et al. (2008) Wood density predicts plant damage and vegetative recovery rates caused by cyclone disturbance in tropical rainforest tree species of North Queensland, Australia. Aust. Ecol., 33, 442-450.

FAO (2007) State of the World's Forests., FAO, Rome, Italy, pp.144.

Fortunel, C. et al. (2012) Leaf, stem and root tissue strategies across 758 Neotropical tree species. Funct. Ecol., 26, 11531161.

Fortunel, C. et al. (2014) Wood specific gravity and anatomy of branches and roots in 113 Amazonian rainforest tree species across environmental gradients. New Phytol., 202, 79-94.

Gardner, S. et al. (2000) Field guide to forest trees of Northern Thailand. Asia Books, Bangkok, pp.545.

Gartner, B. L. et al. (2004) Gas in stems: abundance and potential consequences for tree biomechanics. Tree Physiol., 24, 1239-1250.

Hiromi, T. et al. (2012) Interspecific variation in leaf water use associated with drought tolerance in four emergent dipterocarp species of a tropical rain forest in Borneo. J. For. Res., 17, 369-377.

Holbrook, N. M. et al. (1995) Drought responses of neotropical dry forest trees. In Seasonally dry tropical forests., eds. Bullock S. H. et al., Cambridge University Press, UK, Cambridge, 243-276.

Hozumi, K. et al. (1969) Production ecology of tropical rain forests in southwestern Cambodia. I. Plant biomass. Nat. Life SE. Asia, 6, 1-56.

Ichie, T. et al. (2016) Ecological distribution of leaf stomata and trichomes among tree species in a Malaysian lowland tropical rain forest. J. Plant Res., 129, 625-635.

Iida, S. et al. (2013) Year-to-year differences in sap flow and crown-level stomatal conductance of two species in a lowland evergreen forest, central Cambodia. JARQ, 47, 319-327.

Iida, S. et al. (2016) Interrelationships among dry season leaf fall, leaf flush, and transpiration: insights from sap flux measurements in a tropical dry deciduous forest. Ecohydrol., 9, 472-486.

Iida, Y. et al. (2012) Wood density explains architectural differentiation across 145 co-occurring tropical tree species. Funct. Ecol., 26, 274-282.

Inoue, Y. et al., (2015) Leaf water use in heterobaric and homobaric leafed canopy tree species in a Malaysian tropical rain forest. Photosynthetica, 53, 177-186.

Ishida, A. et al. (2006) Contrasting seasonal leaf habits of canopy trees between tropical dry-deciduous and evergreen forests in Thailand. Tree Physiol., 26, 643-656.

Ishida, A. et al. (2008). Coordination between leaf and stem traits related to leaf carbon gain and hydraulics across 32 drought-tolerant angiosperms. Oecologia, 156, 193-202.

Ishida, A. et al. (2010) Seasonal variations of gas exchange and water relations in deciduous and evergreen trees in monsoonal dry forests of Thailand. Tree Physiol., 30, 935-945.

Kenzo, T. et al. (2007) Ecological distribution of homobaric and heterobaric leaves in tree species of Malaysian lowland tropical rainforest. Am. J. Bot., 94, 764-775.

Kenzo, T. et al. (2009a) Allometric equations for accurate estimation of aboveground biomass in logged-over tropical rainforests in Sarawak, Malaysia. J. For. Res., 14, 365-372.

Kenzo, T. et al. (2009b) Development of allometric relationships for accurate estimation of above- and below-ground biomass in tropical secondary forests in Sarawak, Malaysia. J. Trop. Ecol., 25, 371-386.

Kenzo, T. et al. (2011) Growth and photosynthetic response of four Malaysian indigenous tree species under different light conditions. J. Trop. For. Sci., 23, 271-281.

Kenzo, T. et al. (2012) Variations in leaf photosynthetic and morphological traits with tree height in various tree species in a Cambodian tropical dry evergreen forest. JARQ, $\mathbf{4 6}$, 167-180.

Kenzo, T. et al. (2015) Height-related changes in leaf photosynthetic traits in diverse Bornean tropical rain forest trees. Oecologia, 177, 191-202.

Kenzo, T. et al. (2016a) Morphological and physicochemical traits of leaves of different life forms of various broadleaf woody plants in interior Alaska. Can. J. For. Res., 46, 14751482.

Kenzo, T. et al. (2016b) Wood density and water content in diverse species from lowland dipterocarp rainforest and dry dipterocarp forest. Proc. Symposium Frontier in Tropical Forest Research: Progress in Joint Projects between the Forest Department Sarawak and the Japan Research Consortium for Tropical Forests in Sarawak, 94-103.

Kenzo, T. et al. (2016c) Seasonal and height-related changes in leaf morphological and photosynthetic traits of two dipterocarp species in a dry deciduous forest in Cambodia. Plant Ecol. Diversity, 9, 505-520.

King, D. A. et al. (2005) Tree growth is related to light interception and wood density in two mixed dipterocarp forests of 
Malaysia. Funct. Ecol., 19, 445-453.

King, D. A. et al. (2006) The role of wood density and stem support costs in the growth and mortality of tropical trees. J. Ecol., 94, 670-680.

Kitajima, K. (1994) Relative importance of photosynthetic traits and allocation patterns as correlates of seedling shade tolerance of 13 tropical trees. Oecologia, 98, 419-428.

Komiyama, A. et al. (2005) Common allometric equations for estimating the tree weight of mangroves. J. Trop. Ecol., 21, 471-477.

Lohbeck, M. et al. (2013) Successional changes in functional composition contrast for dry and wet tropical forest. Ecol$o g y, 94,1211-1216$.

Malhi, Y. et al. (2006) The regional variation in aboveground live biomass in old-growth Amazonian forests. Glob. Change Biol., 12, 1107-38.

Markesteijn, L. et al. (2011) Hydraulics and life history of tropical dry forest tree species: coordination of species' drought and shade tolerance. New Phytol., 191, 480-495.

Martin, A. R. et al. (2013) Size-dependent changes in wood chemical traits: a comparison of neotropical saplings and large trees. AoB Plants, 5, plt039.

Meinzer, F. C. et al. (2004) Dynamics of transpiration, sap flow and use of stored water in tropical forest canopy trees. Tree Physiol., 24, 901-909.

Muller-Landau, H. C. (2004) Interspecific and inter-site variation in wood specific gravity of tropical trees. Biotrop., 36, 20-32.

Murata, N. et al. (2012) Soil depth and soil water regime in a catchment where tropical dry evergreen and deciduous forests coexist. J. For. Res., 17, 37-44.

Nakano, T. \& Kaburagi, J. (1966) On the bulk density and shrinkage of eight species of Cambodian wood. Bull. Gov. For. Exp. Stn., 190, 31-61.

Ogawa, H. et al. (1965) Comparative ecological study on three main types of forest vegetation in Thailand. I. Structure and floristic composition. Nat. Life SE. Asia, 4, 13-48.

Ohnuki, Y. et al. (2008) Distribution and characteristics of soil thickness and effects upon water storage in forested areas of Cambodia. Hydrol. Process., 22, 1272-1280.

Onoda, Y. et al. (2010) The relationship between stem biomechanics and wood density is modified by rainfall in 32 Australian woody plant species. New Phytol., 185, 493-501.

Osunkoya, O. O. et al. (2007) Variation in wood density, wood water content, stem growth and mortality among twentyseven tree species in a tropical rainforest on Borneo Island. Aust. Ecol., 32, 191-201.

Pauline, D. P. (2000) Dictionary of plants used in Cambodia. Imprimerie Olympic, Phnom Penh, Cambodia, pp.915.

Poorter, L. (2008) The relationships of wood, gas and water fractions of tree stems to performance and life history variation in tropical trees. Ann. Bot., 102, 367-375.

Poorter, L. \& Kitajima, K. (2007) Carbohydrate storage and light requirements of tropical moist and dry forest tree species. Ecology, 88, 1000-1011.

Poorter, L. et al. (2010) The importance of wood traits and hydraulic conductance for the performance and life history strategies of 42 rainforest tree species. New phytol., 185, 481-492.

Ryan, M. G. et al. (2006) The hydraulic limitation hypothesis revisited. Plant Cell Environ., 29, 367-381.
Saatchi, S. et al. (2007) Distribution of aboveground live biomass in the Amazon basin. Glob. Chang. Biol., 13, 816-837.

Sakurai, K. et al. (1998) Differences in soil properties of dry evergreen and dry deciduous forests in the Sakaerat Environmental Research Station. Tropics, 8, 61-80.

Santiago, L. S. et al. (2004) Leaf photosynthetic traits scale with hydraulic conductivity and wood density in Panamanian forest canopy trees. Oecologia, 140, 543-550.

Slik, J. W. F. et al. (2010) Environmental correlates of tree biomass, basal area, wood specific gravity and stem density gradients in Borneo's tropical forests. Glob. Ecol. Biogeogr., 19, 50-60.

Sobrado, M. A. (1993) Trade-off between water transport efficiency and leaf life-span in a tropical dry forest. Oecologia, 96, 19-23.

Srun, S. M. (2014) Forestry in Cambodia : the dilemma of development and preservation. $\mathrm{N}^{\circ} 14$, Phnom Penh, Cambodia, pp. 148 .

Stegen, J. C. et al. (2009) Aboveground forest biomass is not consistently related to wood density in tropical forests. Glob. Ecol. Biogeogr., 18, 617-625.

Sungpalee, W. et al. (2009) Intra-and interspecific variation in wood density and fine-scale spatial distribution of standlevel wood density in a northern Thai tropical montane forest. J. Trop. Ecol., 25, 359-370.

Suzuki, E. (1999) Diversity in specific gravity and water content of wood among Bornean tropical rainforest trees. Ecol. Res., 14, 211-224.

Tagane, S. et al. (2015) A Picture guide of forest trees in Cambodia III -Kratie-. Center for Asian Conservation Ecology, Kyushu University. Fukuoka, Japan, pp.100.

Tanaka-Oda, A. et al. (2016) Variation in leaf and soil $\delta 15 \mathrm{~N}$ in diverse tree species in a lowland dipterocarp rainforest, Malaysia. Trees, 30, 509-522.

Thomas, S. C. (1996) Asymptotic height as a predictor of growth and allometric characteristics in Malaysian rain forest trees. Am. J. Bot., 83, 556-566.

Top, N. et al. (2009) Effects of population density on forest structure and species richness and diversity of trees in Kampong Thom Province, Cambodia. Biodivers. Cons., 18, 717-738.

Toriyama, J. et al. (2011) Soil pore characteristics of evergreen and deciduous forests of the tropical monsoon region in Cambodia. Hydrol. Process., 25, 714-726.

Toyama, H. et al. (2012) A pictured guide of forest trees in Cambodia I -Kampong Chhnang-. Center for Asian Conservation Ecology, Kyushu University. Fukuoka, Japan, pp. 108 .

Toyama, H. et al. (2013) A pictured guide of forest trees in Cambodia II -Kampong Thom-. Center for Asian Conservation Ecology, Kyushu University. Fukuoka, Japan, pp.278.

Ter Steege, H. \& Hammond, D. S. (2001) Character convergence, diversity, and disturbance in tropical rain forest in Guyana. Ecology, 82, 3197-3212.

Turner, I. M. (2001) The ecology of trees in the tropical rain forest. Cambridge University Press, Cambridge, UK, pp.298.

Wiemann, M. C. \& Williamson, G. B. (2002) Geographic variation in wood specific gravity: effects of latitude, temperature, and precipitation. Wood Fiber., 34, 96-107.

Williamson, G. B. (1984) Gradients in wood specific gravity of trees. Bull. Torrey Bot. Club., 111, 51-55. 
Appendix 1. List of studied tree species, life-forms, wood density (WD, g/cm 3 ), and water content $\left(\mathrm{WC}, \mathrm{g} / \mathrm{cm}^{3}\right)$ in dry evergreen forest (DEF).

\begin{tabular}{|c|c|c|c|c|}
\hline Family & $\begin{array}{l}\text { Species } \\
\end{array}$ & Life-forms & "WD & $\overline{\mathrm{WC}}$ \\
\hline Anacardiaceae & Mangifera duppereana & Subcanopy & 0.602 & 0.422 \\
\hline \multirow[t]{2}{*}{ Annonaceae } & Melodorum fruticosum & Understory & 0.728 & 0.328 \\
\hline & Polyalthia cerasoides & Understory & 0.665 & 0.311 \\
\hline Caesalpiniaceae & Peltophorum cf. dasyrrhachis & Canopy & 0.526 & 0.366 \\
\hline Capparaceae & Capparis sepiaria & Understory & 0.704 & 0.333 \\
\hline Chrysobalanaceae & Parinari anamensis & Canopy & 0.822 & 0.332 \\
\hline \multirow[t]{4}{*}{ Cluciaceae } & Calophyllum thorelii & Canopy & 0.473 & 0.666 \\
\hline & Garcinia multiflora & Understory & 0.858 & 0.349 \\
\hline & Garcinia oblongifolia & Understory & 0.741 & 0.413 \\
\hline & Garcinia schefferi & Understory & 0.694 & 0.421 \\
\hline \multirow[t]{6}{*}{ Dipterocarpaceae } & Anisoptera costata & Canopy & 0.571 & 0.517 \\
\hline & Dipterocarpus alatus & Canopy & 0.499 & 0.520 \\
\hline & Dipterocarpus costatus & Canopy & 0.652 & 0.424 \\
\hline & Hopea odorata & Canopy & 0.637 & 0.394 \\
\hline & Vatica odorata & Subcanopy & 0.727 & 0.327 \\
\hline & Vatica sp. & Subcanopy & 0.732 & 0.269 \\
\hline \multirow[t]{4}{*}{ Ebenaceae } & Diospyros bejaudii & Understory & 0.610 & 0.369 \\
\hline & Diospyros filipendula & Understory & 0.646 & 0.423 \\
\hline & Diospyros montana & Understory & 0.726 & 0.360 \\
\hline & Diospyros undulata & Understory & 0.571 & 0.334 \\
\hline \multirow[t]{2}{*}{ Elaeocarpaceae } & Elaeocarpus petiolatus & Subcanopy & 0.514 & 0.377 \\
\hline & Elaeocarpus poilanei & Subcanopy & 0.689 & 0.382 \\
\hline Euphorbiaceae & Macaranga griffithiana & Canopy gap & 0.290 & 0.345 \\
\hline Fagaceae & Lithocarpus elegans & Subcanopy & 0.677 & 0.414 \\
\hline Icacinaceae & Gomphandra sp. & Understory & 0.579 & 0.524 \\
\hline Irvingiaceae & Irvingia malayana & Canopy & 0.863 & 0.316 \\
\hline Lauraceae & Dehaasia cuneata & Subcanopy & 0.569 & 0.464 \\
\hline \multirow[t]{2}{*}{ Leguminosae } & Albizia corniculata & Understory & 0.633 & 0.563 \\
\hline & Sindora siamensis & Canopy & 0.786 & 0.341 \\
\hline \multirow[t]{2}{*}{ Loganiaceae } & Fagraea fragrans & Canopy & 0.619 & 0.494 \\
\hline & Fagraea racemosa & Canopy gap & 0.570 & 0.558 \\
\hline Malvaceae & Microcos tomentosa & Subcanopy & 0.662 & 0.305 \\
\hline \multirow[t]{2}{*}{ Melastomataceae } & Memecylon laevigatum & Understory & 0.696 & 0.295 \\
\hline & Memecylon scutellatum & Understory & 0.796 & 0.327 \\
\hline Myristicaceae & Myristica iners & Canopy & 0.496 & 0.356 \\
\hline \multirow[t]{6}{*}{ Myrtaceae } & Syzygium angkae & Subcanopy & 0.700 & 0.472 \\
\hline & Syzygium antisepticum & Subcanopy & 0.684 & 0.402 \\
\hline & Syzygium oblatum & Subcanopy & 0.819 & 0.357 \\
\hline & Syzygium sp.1 & Subcanopy & 0.474 & 0.316 \\
\hline & Syzygium sp.2 & Subcanopy & 0.716 & 0.453 \\
\hline & Syzygium sp.3 & Subcanopy & 0.695 & 0.354 \\
\hline Myrtaceae & Tristaniopsis burmanica & Subcanopy & 0.744 & 0.381 \\
\hline Olacaceae & Schoepfia fragrans & Understory & 0.579 & 0.514 \\
\hline Oleaceae & Olea sp. & Understory & 0.474 & 0.349 \\
\hline \multirow[t]{2}{*}{ Phyllanthaceae } & Aporosa ficifolia & Understory & 0.677 & 0.396 \\
\hline & Aporosa planchoniana & Understory & 0.709 & 0.369 \\
\hline Polygalaceae & Xanthophyllum flavescens & Canopy & 0.724 & 0.440 \\
\hline Putranjivaceae & Drypetes sp. & Subcanopy & 0.533 & 0.460 \\
\hline Rubiaceae & Neolamarckia cadamba & Canopy gap & 0.328 & 0.343 \\
\hline Symplocaceae & Symplocos cochinchinensis & Subcanopy & 0.559 & 0.505 \\
\hline Unknown & Unknown & Understory & 0.663 & 0.429 \\
\hline Unknown & Unknown & Understory & 0.817 & 0.299 \\
\hline Unknown & Unknown & Understory & 0.572 & 0.471 \\
\hline
\end{tabular}


Appendix 2. List of studied tree species, life-forms, wood density (WD, g/ $\left.\mathrm{cm}^{3}\right)$, and water content (WC, $\mathrm{g} / \mathrm{cm}^{3}$ ) in dry deciduous forest (DDF).

\begin{tabular}{|c|c|c|c|c|}
\hline Family & Species & Life-forms & WD & "WC \\
\hline \multirow[t]{5}{*}{ Anacardiaceae } & Buchanania cochinchinensis & Canopy & 0.590 & 0.400 \\
\hline & Buchanania reticulata & Understory & 0.441 & 0.404 \\
\hline & Buchanania siamensis & Understory & 0.513 & 0.452 \\
\hline & Gluta cambodiana & Understory & 0.635 & 0.378 \\
\hline & Lannea coromandelica & Subcanopy & 0.429 & 0.553 \\
\hline Bignoniaceae & Heterophragma sulphureum & Subcanopy & 0.513 & 0.483 \\
\hline Burseraceae & Canarium subulatum & Canopy & 0.421 & 0.443 \\
\hline Celastraceae & Lophopetalum wallichii & Canopy & 0.537 & 0.411 \\
\hline Chrysobalanaceae & Parinari anamensis & Canopy & 0.671 & 0.437 \\
\hline \multirow[t]{2}{*}{ Cluciaceae } & Calophyllum sp. & Canopy & 0.563 & 0.420 \\
\hline & Garcinia cowa & Understory & 0.527 & 0.510 \\
\hline \multirow[t]{4}{*}{ Combretaceae } & Terminalia chebula & Canopy & 0.788 & 0.388 \\
\hline & Terminalia mucronata & Canopy & 0.847 & 0.350 \\
\hline & Terminalia tomentosa form glabrous & Canopy & 0.799 & 0.424 \\
\hline & Terminalia tomentosa form hairy & Canopy & 0.835 & 0.398 \\
\hline Dilleniaceae & Dillenia cf. hookeri & Understory & 0.561 & 0.498 \\
\hline \multirow[t]{5}{*}{ Dipterocarpaceae } & Dipterocarpus intricatus & Canopy & 0.681 & 0.486 \\
\hline & Dipterocarpus obtusifolius & Canopy & 0.661 & 0.455 \\
\hline & Dipterocarpus tuberculatus & Canopy & 0.666 & 0.410 \\
\hline & Shorea obtusa & Canopy & 0.814 & 0.361 \\
\hline & Shorea siamensis & Canopy & 0.674 & 0.494 \\
\hline \multirow[t]{2}{*}{ Ebenaceae } & Diospyros ehretioides & Subcanopy & 0.654 & 0.391 \\
\hline & Diospyros pilosanthera & Canopy & 0.636 & 0.341 \\
\hline Lamiaceae & Vitex pinnata & Canopy & 0.697 & 0.393 \\
\hline Lecythidaceae & Careya arborea & Subcanopy & 0.601 & 0.508 \\
\hline \multirow[t]{8}{*}{ Leguminosae } & Acacia harmandiana & Subcanopy & 0.661 & 0.446 \\
\hline & Butea monosperma & Subcanopy & 0.509 & 0.571 \\
\hline & Dalbergia cochinchinensis & Canopy & 0.671 & 0.316 \\
\hline & Dalbergia cultrata & Canopy & 0.699 & 0.385 \\
\hline & Dalbergia lanceolaria subsp. paniculata & Canopy & 0.497 & 0.373 \\
\hline & Dalbergia oliveri & Canopy & 0.527 & 0.345 \\
\hline & Pterocarpus macrocarpus & Canopy & 0.718 & 0.408 \\
\hline & Xylia xylocarpa & Canopy & 0.811 & 0.363 \\
\hline Loganiaceae & Strychnos nux-blanda & Subcanopy & 0.880 & 0.344 \\
\hline Malvaceae & Grewia eriocarpa & Understory & 0.683 & 0.283 \\
\hline Melastomataceae & Memecylon scutellatum & Understory & 0.688 & 0.398 \\
\hline \multirow[t]{3}{*}{ Myrtaceae } & Syzygium antisepticum & Canopy & 0.592 & 0.390 \\
\hline & Syzygium cumini & Canopy & 0.779 & 0.381 \\
\hline & Syzygium oblatum & Canopy & 0.644 & 0.421 \\
\hline Opiliaceae & Melientha suavis & Subcanopy & 0.642 & 0.394 \\
\hline \multirow[t]{4}{*}{ Phyllanthaceae } & Aporosa octandra & Subcanopy & 0.560 & 0.489 \\
\hline & Aporosa villosa & Subcanopy & 0.611 & 0.448 \\
\hline & Bridelia retusa & Subcanopy & 0.570 & 0.383 \\
\hline & Phyllanthus emblica & Understory & 0.674 & 0.365 \\
\hline \multirow[t]{8}{*}{ Rubiaceae } & Catunaregam longispina & Understory & 0.703 & 0.432 \\
\hline & Catunaregam cf. tomentosa & Understory & 0.704 & 0.341 \\
\hline & Catunaregam tomentosa & Understory & 0.684 & 0.390 \\
\hline & Gardenia obtusifolia & Understory & 0.705 & 0.349 \\
\hline & Mitragyna rotundifolia & Canopy & 0.577 & 0.450 \\
\hline & Morinda coreia & Understory & 0.522 & 0.553 \\
\hline & Neonauclea sessilifolia & Canopy & 0.666 & 0.499 \\
\hline & Pavetta indica & Understory & 0.657 & 0.310 \\
\hline Sapotaceae & Madhuca stipulacea & Subcanopy & 0.697 & 0.435 \\
\hline Symplocaceae & Symplocos cochinchinensis & Canopy & 0.571 & 0.537 \\
\hline
\end{tabular}

